Thorax (1964), 19, 436.

\title{
A distribution curve for chronic bronchitis
}

\author{
W. M. THURLBECK AND G. E. ANGUS \\ From the Pathological Institute, McGill University, Montreal, Canada
}

In 1960, Reid described a method of quantitating the bronchial mucous gland hypertrophy that occurs in chronic bronchitis. She expressed the bronchial mucous gland size as a ratio of the bronchial mucous gland thickness to the thickness of the bronchial wall, as measured from the epithelial basement membrane to the inner perichondrium. This ratio was increased in chronic bronchitis, and there was no overlap between the ratios found in the lungs of patients with chronic bronchitis and those found in normal lungs, in a small series of cases. Thurlbeck, Angus, and Paré (1963), using this ratio (the Reid index), confirmed the mucous gland hypertrophy of chronic bronchitis but found that there was an overlap in the Reid index values obtained in bronchitics and in non-bronchitics. Restrepo and Heard (1963) measured the area of bronchial mucous glands as seen in histological sections, and found that the glands were increased in a group of patients with chronic bronchitis when compared with a group of non-bronchitics, but they also found an overlap between the groups. Reid's cases of bronchitis, however, appear to have had more severe disease than the bronchitics in the other two series: none had had bronchitis for less than five years and all had produced large quantities of sputum. Her 'controls' and 'bronchitics' may be from two extremes of a distribution curve. Since chronic bronchitis has been regarded as 'an excess of normal function' (Reid and Simon, 1959), an overlap in mucous gland size in bronchitics and non-bronchitics is perhaps to be anticipated. This has to be reconciled with the Ciba Guest Symposium (1959) definition of chronic bronchitis in which patients either suffer from chronic bronchitis or they do not, a viewpoint which would be supported by finding little or no overlap between the two groups.

Further light might be shed on this issue by investigating the distribution curves of the Reid index and of bronchial mucous gland thickness in a group of random cases. Such curves might settle the problem of overlap or non-overlap between groups of bronchitics and non-bronchitics. In addition to describing the distribution curves of the Reid index and bronchial mucous gland thickness in a random group of necropsies, the present work also refers to the relationship between the Reid index and bronchitis, smoking, and emphysema in a larger group of cases than has previously been reported.

\section{MATERIALS AND METHODS}

RANDOM BRONCHI The lungs and bronchi were examined in a random group of necropsies performed in pre-determined weekly periods. These necropsies were performed on patients 20 years or older who had died in the Royal Victoria Hospital, Montreal. One hundred and fifty necropsies were performed during these periods, and at least one lung was examined in each case. In 61 cases both lungs were examined.

An attempt was made to take three standard transverse blocks from the bronchi of each lung examined. It was not always possible to obtain these standard sections, the usual difficulty being awkwardly placed sagittal cuts through the major bronchi made during preparation for examination of emphysema. The standard blocks were from the main stem bronchus just proximal to its division into lobar branches, the upper lobe bronchus just distal to its origin, and the bronchus immediately proximal to the apical segmental bronchus of the lower lobe. The ratio of the thickness of the bronchial mucous glands to the bronchial wall thickness (inner perichondrium to basement membrane) was calculated using a slight modification (Thurlbeck et al., 1963) of the method described by Reid (1960). The average thickness of the mucous glands used in this calculation was recorded. The measurements were made by G.E.A., who was not aware of the clinical history or necropsy findings. Any histological sections not technically satisfactory were discarded; the major artefact encountered was separation of the sub-epithelial layer from cartilage. The distribution curves of the gland/ wall ratio (Reid index) and bronchial mucous gland thicknesses were plotted.

OTHER CASES Similar bronchial measurements were available from 106 to 138 random necropsies performed at the Massachusetts General Hospital, Bostor, (Thurlbeck, 1963a). The bronchi from these cases were not random but biased toward patients with severe grades of emphysema. Bronchial 
measurements were also available from a further 17 cases from the Massachusetts General Hospital, and 34 from the Royal Victoria Hospital. Nearly all of these latter two groups of patients had pulmonary emphysema, often severe and/or clinically symptomatic.

ASSESSMENT OF EMPHYSEMA The lungs were divided into those with and those without emphysema. Emphysema for the purposes of this paper refers to destructive emphysema only and excludes irregular emphysema, age change, and overinflation. The method of examination of emphysema is described in detail elsewhere (Thurlbeck, 1963a). It is based on a Ciba Guest Symposium (1959) grading system used on formalin-inflated lungs impregnated with barium sulphate, as described by Heard (1958).

ASSESSMENT OF HISTORY OF BRONCHITIS The clinical records of the patients were assessed by W.M.T. without knowledge of the bronchial mucous gland measurements. The patients were divided into four categories :

Chronic bronchitis Patients with productive cough of more than two years' duration, or with productive coughs described as chronic.

Non-bronchitics Patients whose records contained a specific denial of cough, or those who admitted to cough but specifically denied sputum production. They should not be regarded as normals, but as controls determined by retrospective analysis of their records.

Uncertain Those patients who had a productive cough of less than two years' duration; those who admitted to cough and did not specifically deny sputum production; thcse in whom the recorded clinical data were confusing, e.g., a productive cough recorded by one observer but not by another; those who coughed up blood ; those whose charts contained such remarks as 'review of systems negative' or 'respiratory system negative'; those in whom bronchiectasis was found at necropsy.

Unknown Patients in whose charts no reference was made concerning the presence or absence of cough and sputum.
ASSESSMENT OF SMOKING Patients were divided into three categories:

Non-smokers The records of these patients contained a specific denial of smoking.

Smokers These patients were described as smokers in their charts. The group was divided into light, moderate and heavy smokers, ex-smokers, and 'other smokers'. Light smokers smoked one to nine cigarettes per day or were described as such ; moderate smokers smoked 10 to 19 cigarettes per day or were described as moderate smokers; heavy smokers smoked 20 or more cigarettes per day or were described as such. 'Other smokers' consisted of pipe and cigar smokers and patients described simply as 'smokers' in their charts.

Unknown These patients had no data concerning smoking in their records.

\section{RESULTS}

One hundred and one $(67 \%)$ of the 150 random patients had bronchi from which measurements could be made. Table I compares the age and sex characteristics of these 101 patients with the 150 cases from which they were drawn and with 1,000 consecutive necropsies in the same necropsy population. The three groups are comparable. Table II illustrates the sampling of bronchitis, smoking, and emphysema in the group of 101

T A B LE I

AGE AND SEX CHARACTERISTICS OF THE VARIOUS GROUPS

\begin{tabular}{|c|c|c|c|c|c|c|}
\hline & \multicolumn{2}{|c|}{ All Cases } & \multicolumn{3}{|c|}{ Males } & \multirow{2}{*}{$\begin{array}{c}\text { Females } \\
\text { Average } \\
\text { Age } \\
\text { (yr.) }\end{array}$} \\
\hline & No. & $\begin{array}{c}\text { Average } \\
\text { Age } \\
\text { (yr.) }\end{array}$ & No. & $\%$ & $\begin{array}{l}\text { Average } \\
\text { Age } \\
\text { (yr.) }\end{array}$ & \\
\hline $\begin{array}{l}\text { Random necropsies } \\
\text { Cases from random } \\
\text { necropsies with } \\
\text { bronchial measure- }\end{array}$ & 150 & $61 \cdot 1$ & 78 & 52 & 60.8 & $61 \cdot 4$ \\
\hline $\begin{array}{l}\text { ments } \\
1,000 \text { consecutive nec- } \\
\text { ropsies from same } \\
\text { population }\end{array}$ & 101 & $59 \cdot 5$ & 549 & 55 & $60 \cdot 6$ & $60 \cdot 7$ \\
\hline
\end{tabular}

T A B LE I I

SAMPLING OF BRONCHITIS, EMPHYSEMA, AND SMOKING IN THE GROUP FROM WHICH BRONCHIAL MEASUREMENTS WERE AVAILABLE

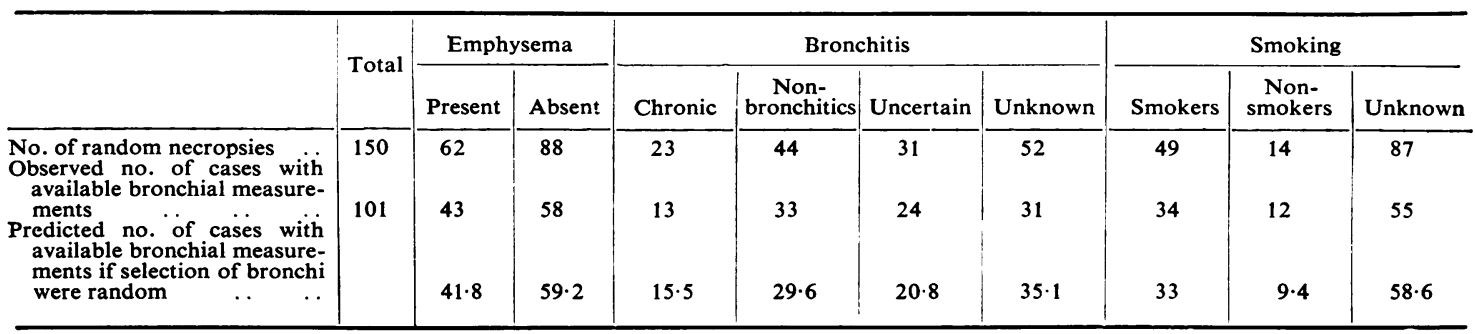


patients compared with the whole group of 150 patients. It is apparent that there has been no bias toward patients with chronic lung disease. Since the Reid index and gland thickness is not only influenced by the presence of emphysema but also by its severity (Thurlbeck and Angus, 1963), Table III shows the sampling within groups ranked according to the severity of the emphysema. The categories reflect the extent and severity of the emphysema and are those described elsewhere (Thurlbeck, 1963b). It is apparent that the sample of bronchi is representative of the larger group of 150 cases with respect to emphysema.

\section{TABLE III}

SAMPLING OF EMPHYSEMA IN GROUP FROM WHICH BRONCHIAL MEASUREMENTS WERE MADE

\begin{tabular}{|c|c|c|c|}
\hline \multirow[b]{2}{*}{$\begin{array}{c}\text { Emphysema } \\
\text { Group }\end{array}$} & \multirow[b]{2}{*}{$\begin{array}{l}\text { No. of } \\
\text { Cases in } \\
\text { Group }\end{array}$} & \multicolumn{2}{|c|}{$\begin{array}{c}\text { Cases with Available Bronchial } \\
\text { Measurements }\end{array}$} \\
\hline & & Observed No. & $\begin{array}{c}\text { Predicted No. if } \\
\text { Selection of Bronchi } \\
\text { were Random }\end{array}$ \\
\hline $\begin{array}{l}\text { None .. } \\
\text { Mild .. } \\
\text { Moderate } \\
\text { Severe.. } \\
\text { All cases }\end{array}$ & $\begin{array}{r}88 \\
39 \\
20 \\
3 \\
150\end{array}$ & $\begin{array}{r}58 \\
26 \\
15 \\
2 \\
101\end{array}$ & $\begin{array}{c}59 \cdot 3 \\
26 \cdot 3 \\
13 \cdot 5 \\
2 \cdot 0 \\
\end{array}$ \\
\hline
\end{tabular}

The distribution curve for the Reid index and bronchial mucous gland thickness in the 101 random cases is shown in Figures 1 and 2. The distribution curve is clearly bell-shaped for both parameters.

Table IV shows the distribution of smokers, chronic bronchitis, and emphysema at various levels of the Reid index for all cases (258) in which this value was available, including the 101 random cases. This Table shows an increasing proportion of bronchitics as the Reid index value increases. An increase in smokers and patients with emphysema is also present as the index increases, but the percentage of smokers and patients with emphysema is much higher at low levels of the Reid index than was the case in bronchitis. The relative proportion of heavy smokers increases strikingly in the groups.

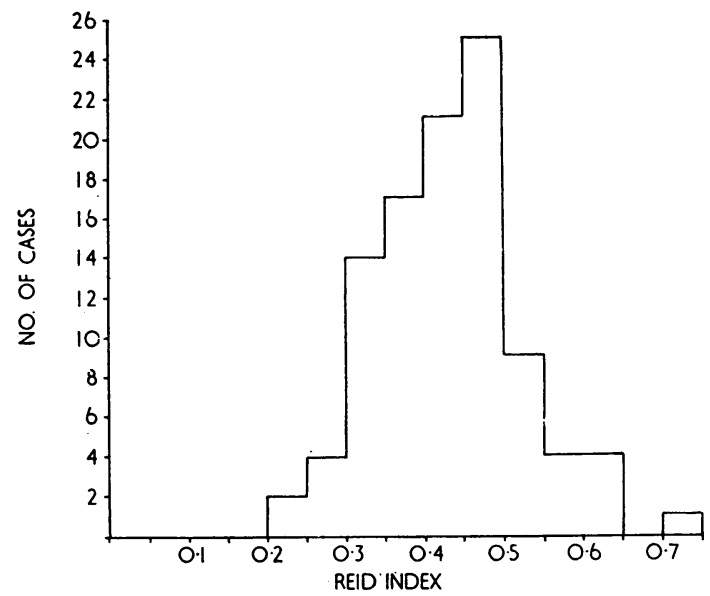

FIG. 1. Reid index values in 101 random necropsies.

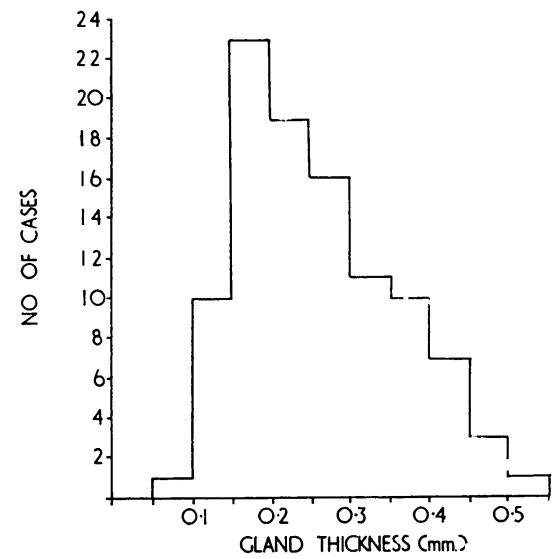

FIG. 2. Bronchial mucous gland size in 101 random necropsies.

Table $\mathrm{V}$ shows the mean Reid index and mean gland thickness in the various groups of patients defined in terms of smoking, bronchitis, and emphysema. From this Table it is apparent that the mean Reid index and mean gland thickness are greater in patients with chronic bronchitis than in non-bronchitics, in smokers than in non-

T A B L E I V

DISTRIBUTION OF SMOKING, BRONCHITIS, AND EMPHYSEMA AT VARIOUS LEVELS OF THE REID INDEX

\begin{tabular}{|c|c|c|c|c|c|c|c|c|c|}
\hline \multirow[b]{2}{*}{ Reid Index } & \multicolumn{3}{|c|}{ Bronchitis } & \multicolumn{3}{|c|}{ Smoking } & \multicolumn{3}{|c|}{ Emphysema } \\
\hline & $\begin{array}{c}\text { Chronic } \\
\text { Bronchitis }\end{array}$ & $\begin{array}{c}\text { Non- } \\
\text { bronchitics }\end{array}$ & $\begin{array}{l}\% \text { with } \\
\text { Bronchitis }\end{array}$ & Smokers & $\begin{array}{c}\text { Non- } \\
\text { smokers }\end{array}$ & $\begin{array}{l}\text { \% Smokers } \\
\text { (heavy } \\
\text { smokers) }\end{array}$ & Emphysema & $\begin{array}{c}\text { No } \\
\text { Emphysema }\end{array}$ & $\begin{array}{c}\% \text { with } \\
\text { Emphysema }\end{array}$ \\
\hline $\begin{array}{c}<0.36 \\
0.36-0.45 \\
0.46-0.55 \\
>0.55\end{array}$ & $\begin{array}{r}1 \\
10 \\
31 \\
21\end{array}$ & $\begin{array}{r}16 \\
29 \\
23 \\
9\end{array}$ & $\begin{array}{r}6 \\
26 \\
57 \\
70\end{array}$ & $\begin{array}{r}6 \\
33 \\
42 \\
30\end{array}$ & $\begin{array}{r}9 \\
12 \\
15 \\
4\end{array}$ & $\begin{array}{l}40(13) \\
73(27) \\
74(47) \\
88(56)\end{array}$ & $\begin{array}{l}16 \\
36 \\
58 \\
32\end{array}$ & $\begin{array}{l}24 \\
48 \\
33 \\
11\end{array}$ & $\begin{array}{l}40 \\
43 \\
64 \\
74\end{array}$ \\
\hline
\end{tabular}


TABLE V

MEAN REID INDEX AND BRONCHIAL MUCOUS GLAND THICKNESS IN GROUPS DEFINED BY BRONCHITIS, SMOKING, AND EMPHYSEMA

\begin{tabular}{|c|c|c|c|c|c|c|c|c|c|c|}
\hline & \multicolumn{4}{|c|}{ Bronchitis } & \multicolumn{4}{|c|}{ Smoking } & \multicolumn{2}{|c|}{ Emphysema } \\
\hline & $\begin{array}{c}\text { Chronic } \\
\text { Bronchitis }\end{array}$ & $\begin{array}{c}\text { Non- } \\
\text { bronchitics }\end{array}$ & Doubtful & $\begin{array}{c}\text { No } \\
\text { Data }\end{array}$ & Smokers & $\begin{array}{c}\text { Non- } \\
\text { smokers }\end{array}$ & $\begin{array}{c}\text { No } \\
\text { Data }\end{array}$ & $\begin{array}{l}\text { Heavy } \\
\text { Smokers }\end{array}$ & Present & Absent \\
\hline 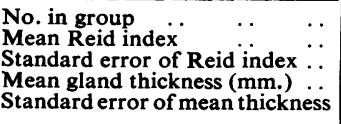 & $\begin{array}{l}63 \\
0.52 \\
0.01 \\
0.34 \\
0.01\end{array}$ & $\begin{array}{l}77 \\
0.44 \\
0 \cdot 01 \\
0 \cdot 24 \\
0.01\end{array}$ & $\begin{array}{l}40 \\
0.42 \\
0.02 \\
0.25 \\
0.02\end{array}$ & $\begin{array}{l}78 \\
0.44 \\
0.01 \\
0.25 \\
0.01\end{array}$ & $\begin{array}{r}111 \\
0.49 \\
0.01 \\
0 \cdot 30 \\
0.01\end{array}$ & $\begin{array}{c}40 \\
0 \cdot 44 \\
0 \cdot 01 \\
0 \cdot 25 \\
0 \cdot 015\end{array}$ & $\begin{array}{r}107 \\
0.43 \\
0.01 \\
0.25 \\
0.01\end{array}$ & $\begin{array}{l}58 \\
0.52 \\
0.01 \\
0 \cdot 31 \\
0.02\end{array}$ & $\begin{array}{r}142 \\
0.48 \\
0.01 \\
0 \cdot 29 \\
0.01\end{array}$ & $\begin{array}{l}116 \\
0.43 \\
0.01 \\
0 \cdot 24 \\
0.01\end{array}$ \\
\hline
\end{tabular}

smokers, and in patients with emphysema than in those without. The difference is significant $(\mathrm{P}<0.05)$ in all and is most striking in bronchitis.

\section{DISCUSSION}

It is quite clear from Figs. 1 and 2 that the distribution curves of the Reid index and of the bronchial mucous gland thickness are bell-shaped. The random samples from which these measurements were made are representative of the necropsy population, and it is apparent from Tables IV and V that only extraordinary selections of bronchitics, smokers, or patients with emphysema would make the curves bimodal. For example, the distribution curve of the measurements made on all cases (258) reported here is bell-shaped, despite the fact that there is a distinct

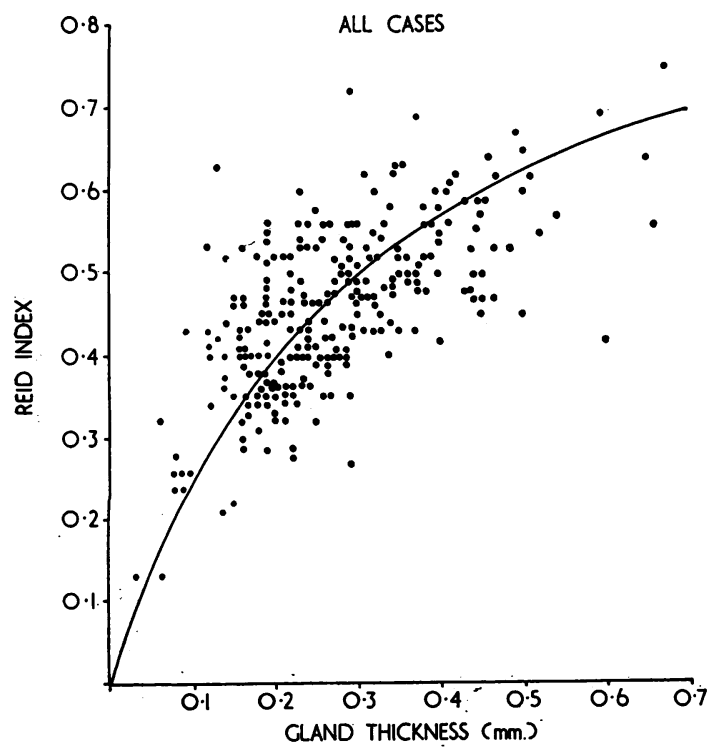

EIG. 3. Relationship of the Reid index to bronchial mucous gland thickness. bias in these cases toward patients with chronic lung disease. The relationship between the Reid index and the bronchial wall thickness is shown in Fig. 3. We have previously shown that the increase in the Reid index that occurs in bronchitis and smoking (Thurlbeck et al., 1963) and in emphysema (Thurlbeck and Angus, 1963) is due to an increase in gland thickness, and that the remainder of the wall was constantly $0.3 \mathrm{~mm}$. thick in all the groups considered. The relationship between the Reid index and the bronchial mucous gland thickness may thus be expressed by the formula

Reid index $=\frac{\text { gland thickness }}{\text { gland thickness }+0 \cdot 3}$. This curve is drawn in Fig. 3. Below 0.7 the numerical value of the Reid index is greater than that of bronchial mucous gland thickness. This shifts the distribution curve of the Reid index to the right compared with the distribution curve of bronchial mucous gland thickness (Figs. 1 and 2), but both curves are bell-shaped.

Two questions may be raised concerning the distribution curves. It may be suggested that they represent variations of measurements of a structure which is really constant in size. For example, mucous glands may be considered to be roughly spherical, and measurements are made of transverse sections through this structure. The distribution curve of such transverse measurements made through a sphere might be anticipated to be bellshaped. In such circumstances, the distribution of bronchitis, smoking, and emphysema should be random at various levels of the Reid index or gland thickness. This is clearly not the case, and at one end of the curve the patients are generally non-bronchitic, non-smokers, and without emphysema, and at the other end they are generally bronchitic, smokers, and have emphysema (Table IV). It might also be questioned whether the distribution curve represents normal biological variation of mucous gland size, and whether 
patients are bronchitic because they have large mucous glands rather than vice versa. Epidemiological data pointing out the importance of environmental factors in the production of clinical chronic bronchitis make this unlikely. Indeed, our own data suggest that environmental factors are important. At Reid index levels below 0.36, 40\% were smokers (13\% heavy smokers), and at Reid index levels over $0.55,88 \%$ were smokers $(56 \%$ heavy smokers). Put in another way, the mean Reid index level was 0.44 in non-smokers, 0.49 in smokers, and 0.52 in heavy smokers. Clearly, the Reid index is affected by smoking.

Since the distribution curves are bell-shaped, there must be an overlap between the values recorded in bronchitics and in non-bronchitics, as had previously been reported by ourselves using the Reid index (Thurlbeck et al., 1963), and by Restrepo and Heard (1963), using gland areas. While it is true that retrospective analysis of the clinical histories of patients with chronic bronchitis has inherent deficiencies, the nature of the distribution curve is such that no matter how carefully the history of bronchitis might be determined such an overlap is inevitable. It follows that measurements on individual cases have limited value in correlating clinical and morphological bronchitis. The exact limitations of these measurements in individual cases is not entirely clear from our data, but the limitations in the Reid index values of 0.36 to 0.55 is apparent (Table IV). In the present material, the one chronic bronchitic with a Reid index level below 0.36 was a 73 -year-old man with a long history of cough productive of green sputum. No smoking history was recorded. Death was due to peritonitis following perforation of a diverticulum. He had a moderate degree of mixed centrilobular, panlobular, and paraseptal emphysema. No bronchiectasis or other pulmonary cause for chronic bronchitis was found, nor the reason for his green sputum. Three adequate bronchial sections were available from each lung. The Reid index was 0.34 , and the bronchial gland thickness was 0.19 $\mathrm{mm}$. The number of mucous acini was not disproportionately high (Glynn and Michaels, 1960), and the number of acini per unit high puwer was 23, within normal limits (Thurlbeck et al., 1963). Remeasurements by two observers on three separate occasions gave a similar result, although one reading was 0.38 , thus moving the case into another group. There seems no doubt that he was clinically a chronic bronchitic and that the mucous glands were normal. Conceivably this may represent 'atrophy', which is said to occur in chronic bronchitis (Kourilsky, Decroix, Verley, 들. Matossy, Hinglais, Pieron and Brille, 1960), but $\frac{\bar{\omega}}{\sigma}$ the morphological appearance of the glands $\stackrel{\odot}{\varrho}$ differed in no way from that of others of a similar size.

The mean Reid index in non-bronchitics reported here is higher $(0.44)$ than that reported $\vec{\omega}$ by Reid (1960) and by ourselves (Thurlbeck et al., 1963 ) in surgical material. These figures were $0 \cdot 26 \times$ and 0.37 respectively. This perhaps lends credence $\vec{\theta}$ to the view that some of our patients who were ir recorded as specifically denying chronic bronchitis $\vec{\omega}$ may indeed have been producing sputum but did not admit this to the examining physician. Fletcher and Tinker (1961) have also observed that about one fifth of patients who deny sputum $\mathbb{D}$ production in questionnaires astually produce sputum into specimen cups in the winter. Thus it may be also that a somewhat higher proportion $\mathbb{D}$ of patients with a Reid index value of over 0.55 actually produced sputum than the figure of $70 \%$ quoted here. A review of the pathological data in the nine $(30 \%)$ patients deemed to be nonbronchitic but with Reid index values over 0.55 confirmed the previous assessment. Whether these are examples of wrong information imparted by the patient, or incorrect recording of the patients' information, or whether the data were correct, it is impossible to say. This emphasizes the need for a prospective experiment correlating mucous gland hypertrophy with an assessment of bronchitis using a standard questionnaire. We have previously described a clinical non-bronchitic determined in this way who had a Reid index of 0.54 (Thurlbeck et al., 1963).

The Reid index should be a better measure of gland hypertrophy than absolute measurements of gland thickness or area, since the latter are likely to be inifuenced by oblique cuts through the bronchial wall and variable shrinkage of tissue during preparation for histological examination. Further, absolute gland size may be a function of body size, in the way that most organs are. These variations are likely to be corrected by the Reid index which is a ratio, and artificial increases accompanied by similar artificial increases in wall thickness will be corrected. That the index is more informative than absolute measurements is shown in Table VI. This shows the percentage of bronchitics, smokers, and patients with emphysema in groups ranked by gland thickness. Once again, at low levels the patients are generally non-bronchitic, non-smokers, and without emphysema, and the reverse is true at high levels. However, the difference between high and low levels is not as 
TABLE VI

DISTRIBUTION OF BRONCHITIS, SMOKING, AND EMPHYSEMA AT VARIOUS LEVELS OF GLAND THICKNESS

\begin{tabular}{|c|c|c|c|c|c|c|c|c|c|}
\hline \multirow{2}{*}{$\begin{array}{l}\text { Gland } \\
\text { Thickness } \\
\text { (mm.) }\end{array}$} & \multicolumn{3}{|c|}{ Bronchitis } & \multicolumn{3}{|c|}{ Smoking } & \multicolumn{3}{|c|}{ Emphysema } \\
\hline & $\begin{array}{l}\text { Chronic } \\
\text { Bronchitis }\end{array}$ & $\begin{array}{c}\text { Non- } \\
\text { bronchitics }\end{array}$ & $\begin{array}{l}\% \text { with } \\
\text { Bronchitis }\end{array}$ & Smokers & $\begin{array}{l}\text { Non- } \\
\text { smokers }\end{array}$ & $\begin{array}{c}\% \\
\text { Smokers }\end{array}$ & Present & Absent & $\begin{array}{c}\% \text { with } \\
\text { Emphysema }\end{array}$ \\
\hline $\begin{array}{c}<0.17 \\
0.17-0.25 \\
0.26-0.37 \\
0.38+\end{array}$ & $\begin{array}{r}4 \\
15 \\
21 \\
23\end{array}$ & $\begin{array}{r}17 \\
32 \\
19 \\
9\end{array}$ & $\begin{array}{l}19 \\
32 \\
53 \\
72\end{array}$ & $\begin{array}{l}11 \\
32 \\
44 \\
24\end{array}$ & $\begin{array}{r}8 \\
17 \\
8 \\
7\end{array}$ & $\begin{array}{l}58 \\
65 \\
85 \\
78\end{array}$ & $\begin{array}{l}12 \\
44 \\
59 \\
27\end{array}$ & $\begin{array}{l}29 \\
45 \\
26 \\
16\end{array}$ & $\begin{array}{l}29 \\
49 \\
69 \\
63\end{array}$ \\
\hline
\end{tabular}

great, nor the step-wise increases in the groups as striking as in the corresponding Table using the Reid index values. It seems reasonable, therefore, to use the Reid index rather than absolute measurements of gland thickness.

The fact that the Reid index has limitations in correlating clinical bronchitis and morphological bronchitis, as assessed by mucous gland hypertrophy, in individual instances should not obscure the fact that the Reid index is a valuable measurement for studying groups of cases. The measurement provides a simple, objective way to assess mucous gland hypertrophy and is adequately reproducible (Reid, 1960; Thurlbeck et al., 1963). It distinguishes clearly groups of bronchitics from groups of non-bronchitics. The Reid index has a clear-cut value in making objective assessments in groups of cases and in epidemiological studies of such groups.

The difficulty of correlation in individual cases is due to the fact that the distribution curve of the Reid index is bell-shaped. It follows that there is a gradual and imperceptible change from 'normal' to 'chronic bronchitis'. In general, the more enlarged the bronchial glands, the more likely is a patient to produce sputum, but there are many exceptions (Table IV). A quite considerable degree of gland hypertrophy is present before the majority of patients admit to chronic sputum production, and varying degrees of gland enlargement may be detected pathologically when patients deny sputum production. Since the Ciba Symposium (1959) definition of chronic bronchitis is such that either subjects have this condition or they do not, rigid use of this definition results in problems in correlation. This concept of bronchitis is at variance with the morphological observations recorded here, and it should be questioned which most accurately represents the disease process. The definition of chronic bronchitis as productive cough measures indirectly the final event of a process which results from mucous gland hypertrophy and hence excessive intrabronchial secretion. There is no guarantee that the amount (or presence) of sputum produced by the patient reflects accurately the amount of secretion into the bronchial tree, and even less that the patient will describe the former accurately. In these circumstances the clinical definition of chronic bronchitis as chronic productive cough may be an artificial one, and a more discriminating assessment of intrabronchial mucus production in individual cases may be the Reid index.

We do not wish to suggest that chronic bronchitis should be redefined in anatomical terms, since an anatomical definition is neither theoretically nor practically possible. However, we wish to point out that observers interested in chronic non-specific lung disease should anticipate difficulties in clinico-pathological correlative studies. For example, instances will be found of patients who deny productive cough and yet have bronchial mucous gland hypertrophy. Such patients may not be producing sputum clinically but nevertheless they are hypersecreting mucus into the bronchial tree.

A number of unavoidable deficiencies are present in our material. In the first instance, the population studied is a selected one, namely hospital patients who die and are necropsied. The prevalence of chronic bronchitis in such patients, compared with the non-hospitalized population from which they are drawn, is not known. However, chronic bronchitis is so common and its course so typically protracted that hospitalization and death may be regarded as incidental occurrences in many instances. If this selection from the population at large is to affect the observed distribution curves, it would require that a disproportionately large population with intermediate values of bronchial mucous gland size be admitted to hospital and die, thus converting a bimodal curve to a bell-shaped one. This seems unlikely. The second deficiency is that only bronchial mucous glands have been considered as a source of intrabronchial mucus. Reid (1960) has given reasons why bronchial mucous glands, rather than goblet cells, should be regarded as the source of most intrabronchial mucus. However, some instances of clinical bronchitis with normal 
bronchial mucous glands may result from excessive mucus secretion from goblet cells.

\section{SUMMARY}

Bronchial mucous gland hypertrophy was assessed by measuring the gland to wall ratio (Reid index) and the thickness of the bronchial mucous glands in 101 random necropsies. representative of the necropsy population of the Royal Victoria Hospital, Montreal. The distribution curve for both parameters was bell-shaped. In these circumstances it is inevitable that there should be an overlap in the measurements obtained in bronchitics and in non-bronchitics.

The same measurements were also available from 157 further necropsies. At low values of the Reid index and bronchial mucous gland thickness, patients were generally non-bronchitic, nonsmokers, and usually did not have emphysema. At high levels the reverse was true.

The Reid index is probably a more meaningful measurement of mucous gland hypetrophy than absolute measurement of bronchial mucous gland thickness. The Reid index may be a more discriminating assessment of chronic bronchitis, when defined as excessive intra-bronchial mucus production, than a clinical assessment which divides the population into two classes, those who have chronic productive cough and those who do not. Perhaps we should think more carefully about definitions of chronic bronchitis.

This study was supported by the Committee on Medical Research of the American Thoracic Society, by the Medical Research Council of Canada, and by a Dominion-Provincial Grant No. 604-7-266 of Canada. Further support was received from the Hartford Foundation.

\section{REFERENCES}

Ciba Guest Symposium (1959). Terminology, definitions, and classification of chronic pulmonary emphysema and related conditions. Thorax, 14, 286

Fletcher, C. M., and Tinker, C. M. (1961). Chronic bronchitis: A further study of simple diagnostic methods in a working population. Brit med. J., 1, 1491.

Glynn, A. A., and Michaels, L. (1960). Bronchial biopsy in chronic bronchitis and asthma. Thorax, 15, 142.

Heard, B. E. (1958). A pathological study of emphysema of the lungs with chronic bronchitis. Ibid., 13, 136.

Kourilsky, R., Decroix, G., Verley, J. M., Matossy, Y., Hinglais, J. C., Pieron, R., and Brille, D. (1960). Histologie de la muqueuse bronchique au cours des inflammations chroniques non tuberculeuses des bronches. (Etude sur prélèvements biopsiques.) Bronches, 10, 76 .

Reid, L., and Simon, G. (1959). Chronic bronchitis and emphysema : A Symposium. III. Pathological findings and radiological changes in chronic bronchitis and emphysema. Brit. J. Radiol., 32, 291.

(1960). Measurement of the bronchial mucous gland layer: A diagnostic yardstick in chronic bronchitis. Thorax, 15, 132 .

Restrepo, G., and Heard, B. E. (1963). The size of the bronchial glands in chronic bronchitis. J. Path. Bact., 85, 305.

Thurlbeck, W. M. (1963a). The incidence of pulmonary emphysema. With observations on the relative incidence and spatial distribution of various types of emphysema. Amer. Rev. resp. Dis., 87 206.

(1963b). A clinico-pathological study of emphysema in an American hospital. Thorax, 18, 59.

and Angus, G. E. (1963). The relationship between emphysema and chronic bronchitis as assessed morphologically. Amer. Rev. resp. Dis., 87, 815 .

— and Paré, J. A. P. (1963). Mucous gland hypertrophy in chronic bronchitis, and its occurrence in smokers. Brit. J. Dis. Chest, 57, 73 . 